\title{
PERAMALAN PENENTUAN JUMLAH PERMINTAAN KONSUMEN BERBASIS TEKNOLOGI INFORMASI TERHADAP PRODUK BORDIR PADA KOTA TASIKMALAYA
}

\author{
Lies Sunarmintyastuti ${ }^{1}$, Salman Alfarisi ${ }^{2}$, Fitria Sari Hasanusi ${ }^{3}$ \\ Program Studi Teknik Informatika,Fakultas Teknik, Matematika dan IPA \\ Universitas Indraprasta PGRI Jakarta \\ liesbina@yahoo.com ${ }^{1}, \underline{\text { salman.hotaru@gmail.com }}^{2}$, hasanfitria26@gmail.com $^{3}$
}

\begin{abstract}
Forecasting the determination of the consumer demand number of information technology for products of embroidery on the city of Tasikmalaya, has a special purpose to determine the amount of consumer demand needs periodically, periodic and pattern of consumer demand needs in the future as the trend, seasonal. This study started from the concept of thinking how to make embroidery manufacturers in Tasikmalaya obtain optimal revenue and efficiency in the production cost of their embroidery.Forecasting approach in this study was Time Series by using the Single Exponential Smoothing model to get forecasting value periodically, Double Exponential Smoothing model to get the forecasting value in trend and Triple Exponential SmoothingModel with Multiplicative seasonal mode to get forecasting value seasonal, as well as testing forecasting by using MAD, MAPE and MSE to search for the smallest error. In the next stage, it is built a forecasting system of determining consumer demand by using the method of waterfall development system and the making of softwarewhich is designed by using the Java programming language with the NetBeans editor and MySQL database.
\end{abstract}

Keywords: forecasting, embroidery, exponential smoothing, netbeans

\begin{abstract}
ABSTRAK
Peramalan penentuan jumlah permintaan konsumen berbasis teknologi informasi terhadap produk bordir di Kota Tasikmalaya, mempunyai tujuan khusus untuk menentukan jumlah kebutuhan permintaan konsumen secara periodik, berkala dan pola kebutuhan permintaan konsumen dimasa yang akan datang secara trend, musiman. Penelitian ini berawal dari konsep pemikiran bagaimana supaya produsen bordir di Kota Tasikmalaya mendapatkan pendapatan yang optimal dan efisien dalam biaya produksi bordir mereka. Pendekatan peramalan dalam penelitian ini menggunakan metode Time Series dengan menggunakan Single Exponential Smoothing Modeluntuk mendapatkan nilai peramalan secara periodik, Double Exponential Smoothing Modeluntuk mendapatkan nilai peramalan secara trend dan Triple Exponential SmoothingModeldengan Multiplicative Seasonal Modeluntuk mendapatkan nilai peramalan secara musiman, serta pengujian peramalan menggunakan MAD, MAPE dan MSE untuk mencari error terkecil. Pada tahap berikutnya dibangun sebuah sistem peramalan penentuan permintaan konsumen dengan menggunakan metode pengembangan sistem waterfall dan pembuatansoftware yang dirancang menggunakan bahasa pemrograman Java dengan editor NetBeans dan database MySQL.
\end{abstract}

Katakunci: peramalan, bordir, exponential smoothing, netbeans

\section{PENDAHULUAN}

Pada periode saat ini untuk menghadapi era globalisasi banyak perusahan dalam menjalankan strategi bisnisnya mencoba untuk mengoptimalkan produksi dengan menggunakan beberapa cara atau sistem dengan tujuan untuk efisiensi biaya. Permasalahan yang terjadi biasanya adalah tidak sinkronnya informasi antara departemen produksi dengan departemen penjualan dan dengan bagian distribusi. Hal ini sangat berdampak pada total biaya yang di keluarkan perusahan yang akan mengakibatkan pengurangan laba, bahkan dapat terjadi menurunnya laba perusahaan.

Salah satu upaya dalam permasalahan tersebut adalah dengan melakukan perencanaan produksi bordir seefisien dan seakurat mungkin untuk memaksimalkan total laba, dengan melaksanakan peramalan permintaan konsumen. Berikutnya adalah menentukan penggunaan dana yang efisien, pengaturan waktu produksi untuk meminimalkan biaya produksi. Penelitian ini menitik beratkan bagaimana cara mengoptimalkan perencanaan dan peramalan 
jumlah permintaan konsumen untuk produk bordir berdasarkan data penjualan sebelumnya.

Haryati Embroidery Collection, Zianka Art Bordir adalah merupakan salah satu produsen bordir di daerah Kawalu Tasikmalaya yang merupakan sentra Industri hiasan Bordir di Tasikmalaya. Produk yang dihasilkan oleh Haryati Embrodery Collection, Zianka Art Bordir antara lain, Kebaya, Mukena, Tunik, Selendang, Blus, Rok, Sprei, Sarung Bantal, Taplak Meja, Baju Gamis, Baju Koko, kerudung dan Kopiah Haji. Selanjutnya para pengusaha bordir juga mendirikan Koperasi yang bernama GAPEBTA (Gabungan Pengusaha Bordir Tasikmalaya) sebagai suatu lembaga yang didirikan oleh para pengusaha bordir yang terpanggil berperan aktif membangun dan mengembangkan potensi dan kemampuan ekonomi masyarakat bordir melalui kegiatan positif dalam suatu wadah yang memenuhi aspek yuridis. Jenis produk yang sangat diminati, permintaan tinggi di pasar, khususnya hasil produk dari pengusaha bordir yang tergabung dalam koperasi GAPEBTA dan yang berjualan di Tanah Abang adalah Baju Koko. Meskipun produk jenis lainnya juga banyak peminatnya.

Kemajuan teknologi informasi memungkinkan kegiatan peramalan saat ini dapat dilakukan dengan mudah lewat bantuan komputer. Untuk mengatasi masalah yang ada, maka dibutuhkan suatu rancang bangun aplikasi peramalan. Aplikasi peramalan ini dapat mempercepat perhitungan peramalan, sehingga hasil peramalan tersebut dapat membantu para produsen bordir salah satunya yang berlokasi di Tasikmalaya. Aplikasi peramalan tersebut digunakan untuk perkiraan penentuan jumlah produk yang harus diproduksi dengan tepat dan bermutu. Sistem yang dirancang bangun ini menggunakan bahasa pemrograman java sebagai aplikasi penyelesaian perhitungan peramalan untuk data produksi yang berdasarkan data penjualan untuk pola permintaan konsumen secara periodik,trend dan musiman.

\section{TINJAUAN PUSTAKA}

\section{Peramalan}

Jay Heizer dan Barry Render (2015), menyatakan bahwa peramalan adalah suatu senidanilmupengetahuandalammemprediksi peristiwa-peristiwa pada masa mendatang. Peramalan akan melibatkan mengambil data historis (seperti penjualan tahun lalu) dan memproyeksikan mereka kemasa yang akan datang dengan model matematika. William J.Stevenson dan Sum Chee Chuong (2014) menyatakan bahwa peramalan (forecast) adalah pernyataan mengenai nilai yang akan datang dari variable seperti permintaan. Artinya ramalan adalah prediksi mengenai masa depan. Sedangkan Sofjan Assauri (2016) menyatakan bahwa prakiraan ramalan adalah kegiatan memprediksi nilai masa depan, dengan dasar pengetahuan atau nilai masa lalu yang dipersiapkan. Prakiraan ramaln mencakup penggunaan data historis, dengan memproyeksikannya untuk masa depan yang menggunakan jenis model matematis. Berdasarkan beberapa definisi di atas, pada hakikatnya peramalan merupakan suatu keputusan tentang kemungkinan masa yang akan datang yang didasarkan fakta-fakta ekonomi sekarang dan sejarah masa lalu. Sebelum melakukan peramalan harus diketahui lebih dulu persoalan dalam pengambilan keputusan. Dengan adanya peramalan manajemen dapat segera menyiapkan langkah paling baik dalam mengatasi permasalahan dan dapat bersiap-siap memanfaatkan situasi jika terjadi perkembangan yang lebih baik dalam peramalan. Peramalan yang menjadi titik tolak bagi tindakan perusahaan adalah ramalan penjualan. Pengertian ramalan penjualan adalah proyeksi teknis permintaan konsumen yang potensial pada masa yang akan datang dengan menggunakan berbagai pendekatan. Hal ini sangat berhubungan dengan kegiatan produksi. Dalam proses produksi kegiatan yang dilaksanakan dalam 
peramalan adalah untuk menentukan jumlah permintaan konsumen terhadap suatu produk yang dilakukan pada awal proses perencanaan dan untuk kepentingan proses pengendalian produksi. Oleh sebab itu perangkat lunak sangat dibutuhkan, untuk mendukung peramalan permintaan konsumen untuk mempercepat,mempermudah dan menghindari hitungan dengan tangan yang kemungkinan terjadi kesalahan.

\section{Pendekatan Peramalan}

Menurut Jay Heizer dan Barry Render (2015), terdapat dua pendekatan umum untuk peramalan, hanya terdapat dua cara untuk mengatasi seluruh permodelan keputusan. Salah satu adalah analisis kuantitatif, yang satunya lagi adalah pendekatan kualitatif. Didalam metode peramalan kualitatif tidak digunakan perhitungan-perhitungan dengan rumus dan metode yang pasti melainkan melalui pendapat dari berbagai pihak. Metode peramalan kualitatif antara lain didasarkan pada penilaian dan opini (Opini dewan Eksekutif, Opini bagian Penjualan), Survei Pasar, Metode Delphi. Sedangkan Metode peramalan kuantitatif adalah metode peramalan yang sangat mengandalkan pola data historis yang dimiliki. Pada metode kuantitatif menggunakan metode yang berhubungan dengan ilmu statistik dan matematika, sehingga dapat dipertanggungjawabkan secara ilmiah. Metode kuantitatif dikelompokan menjadi dua jenisyaitu : analisis sebab-akibat (Causal Methods) yang didasarkan atas pengguna analisa pola hubungan antara variabel yang akan diperkirakan dengan variabel lain yang mempengaruhinya dan analisa deret berkala (Time Series) yang pada umumnya selalu berdasarkan atas penggunaan analisa pola hubungan antara variabel yang akan diperkirakan dengan variabel waktu. Metode ini merupakan metode peramalan yang memperkirakan permintaan konsumen/ penjualan periode yang akan datang dengan menggunakan data historis.
Ada 3 (tiga) teknik untuk menghitung deret berkala terdiri dari: metode ratarata bergerak (Moving Average), rata-rata bergerak tertimbang (weight average) dan penghalusan eksponensial (Exponential Smoothing). Penjelasan dari ketiga teknik menghitung rata-rata pada metode analisa deret berkala (Time Series) adalah sebagai berikut:

a. Metode Rata-Rata Bergerak (Moving Average)

Rata-rata bergerak (Moving Average) mengembangkan suatu model berdasarkan hasil perhitungan rata-rata dari sebagian besar penelitian dengan menggunakan persamaan :

$\mathrm{F}_{1}=1\left(\mathrm{~A}_{\mathrm{t}-1}+\mathrm{A}_{\mathrm{t}-2}+\ldots \ldots \ldots . .+\mathrm{A}_{\mathrm{z}}\right) / \mathrm{N}$

Penjelasan :

$\mathrm{F}_{1}=$ Hasil peramalan untuk periode $\mathrm{t}$

$\mathrm{N}=$ jumlah data penelitian

$\mathrm{A}_{\mathrm{t}}=$ data historis penjualan/permintaan konsumen.

$\mathrm{A}_{\mathrm{t}-2} \ldots . \mathrm{Az}=$ data historis penjualan/ permintaan konsumen periode 2 hingga ${ }_{t-n}$

b. Metode Rata-Rata Bergerak Tertimbang (Weighted Moving Average)

Metode ini sama dengan rata-rata bergerak, tetapi nilai terbaru dalam deret berkala diberikan beban lebih besar untuk menghitung peramalan.

Secara matematis, rata-rata bergerak tertimbang ditunjukan sebagai berikut :

Rata-rata bergerak tertimbang $=$

$$
\mathrm{w}_{\mathrm{n}} \mathrm{A}_{\mathrm{t}-\mathrm{n}}+\mathrm{w}_{\mathrm{n}-1} \mathrm{~A}_{\mathrm{t}-(\mathrm{n}-1)}+\ldots \mathrm{w}_{1} \mathrm{~A}_{\mathrm{t}-1}
$$

Dimana :

$\mathrm{W}_{\mathrm{n}}$ = bobot yang diberikan pada nilai terbaru

$\mathrm{A}_{\mathrm{t}-1}=$ nilai aktual pada periode $\mathrm{t}-1$

c. Metode Penghalusan Eksponensial (Exponential Smoothing)

Peramalan Penghalusan Eksponensial (Exponential Smoothing) merupakan salah satu kategori metode time series yang menggunakan pembobotan data masa lalu untuk melakukan peramalan. Besarnya bobot berubah menurun secara eksponensial bergantung pada data histori. 
Berdasarkan bobot yang digunakan, metode Exsponental terbagi menjadi tiga jenis yaitu:

1) MetodeSingle Exponential Smoothing

Metode ini memberikan bobot berdasarkan level $(\alpha)$

Bentuk matematis dari metode Single Exponential Smoothing ditunjukan sebagai berikut:

$$
F_{t}=\alpha A_{t-1}+(1-\alpha) F_{t-1}
$$

Dimana,

$$
\begin{aligned}
F_{t} & =\text { Ramalan Baru } \\
F_{t-1}= & \text { Ramalan Sebelumnya } \\
\alpha & =\text { Konstanta Penghalu } \\
A_{t-1}= & \text { Permintaan aktual periode } \\
& \text { Sebelumnya }
\end{aligned}
$$

2) Metode Double Exponential Smoothing (Metode Holt)

Metode ini merupakan pengembangan dari Single Exponential dimana menambahkan unsur trend pada bobot perhitungan, sehingga pada Double Exponential Smoothing (Metode Holt) kita memberikan dua jenis bobot pada perhitungan yaitu level $(\alpha)$ dan trend $(\beta)$ Bentuk matematis dari Double Exponential Smoothing ditunjukan sebagai berikut :

$$
\begin{aligned}
& A_{t}=\alpha Y_{t}+(1-\alpha)\left(A_{t-1}+T_{t-1}\right) \\
& T_{t}=\beta\left(A_{t}-A_{t-1}\right)+(1-\beta) T_{t-1} \\
& F_{t+m}=A_{t}+T_{t} m \\
& \mathrm{~A}_{\mathrm{t}} \quad=\text { nilai pemulusan eksponensial } \\
& \alpha \quad=\text { konstanta pemulusan untuk data } \\
& \quad(0 \leq \alpha \leq 1) \\
& \beta \quad=\text { konstanta pemulusan untuk estimasi } \\
& \quad \text { trend }(0 \leq \beta \leq 1) \\
& \mathrm{Y}_{\mathrm{t}} \quad=\text { nilai aktual pada periode } \mathrm{t} \\
& \mathrm{T}_{\mathrm{t}} \quad=\text { estimasi trend } \\
& \mathrm{F}(\mathrm{t}+\mathrm{m})=\text { Nilai ramalan }
\end{aligned}
$$

\section{3) Metode Triple Exponential Smoothing} Metode Triple ExponentialSmoothing atau dapat dikenal dengan nama "Winter's Method",merupakan pengembangan dari
Double Exponential dimana melakukan peramalan dengan tiga parameter dengan bobot yang berbeda yaitu level $(\alpha)$, trend $(\beta)$ dan seasonal $(\gamma)$

Berdasarkan tipe musiman (Triple Exponential Smoothing) dibagi menjadi dua yaitu:

- Multiplicative Seasonal Model

- Additive Seasonal Model

Perbedaan antara Multiplication Seasonal Model dengan Additive Seasonal adalah sebagai berikut:

Pada Multiplicative Seasonal Model yaitu mengalikan hasil perhitungan level dan trend dengan perhitungan Seasonal. Sedangkan Additive Seasonal Model yaitu menambahkan hasil perhitungan level dan trend dengan perhitungan Seasonal. Tetapi yang akan di bahas disini hanya Triple Exponential Smoothing dengan Multiplicative Seasonal Model

$$
\begin{aligned}
& A_{t}=\alpha \frac{Y_{t}}{S_{t-L}}+(1-\alpha)\left(A_{t-1}+T_{t-1}\right) \\
& T_{t}=\beta\left(A_{t}-A_{t-1}\right)+(1-\beta) T_{t-1} \\
& S_{t}=\mu \frac{Y_{t}}{A_{t}}+(1-\mu) S_{t-L} \\
& \hat{Y}_{t+p}=\left(A_{t}+T_{t} p\right) S_{t-L+p}
\end{aligned}
$$

$\mathrm{A}_{\mathrm{t}}=$ nilai pemulusan eksponensial

$\alpha=$ konstanta pemulusan untuk data

$$
(0 \leq \alpha \leq 1)
$$

$\beta=$ konstanta pemulusan untuk estimasi trend $(0 \leq \beta \leq 1)$

$\mu=$ konstanta pemulusan untuk estimasi musiman $(0 \leq \mu \leq 1)$

$\mathrm{Y}_{\mathrm{t}}=$ nilai aktual pada periode $\mathrm{t}$

$\mathrm{T}_{\mathrm{t}}=$ estimasi trend

$\mathrm{S}_{\mathrm{t}}=$ estimasi musiman

$\mathrm{L}=$ panjangnya musim

$\mathrm{p}=$ jumlah periode ke depan yang akan diramalkan

\section{Mengukur Kesalahan Peramalan}

Beberapa ukuran yang digunakan dalam praktiknya untuk menghitung keseluruhan dalam kesalahan peramalan. Ukuran-ukuran ini dapat digunakan 
untuk membandingkan model peramalan yang berbeda, sejalan dengan untuk memonitor peramalan untuk memastikan bahwa mereka berfungsi dengan baik. Tiga ukuran yang paling terkenal adalah deviasi rata-rata yang absolut (mean absolute deviation--MAD), kesalahan rata-rata-rata yang dikuadratkan (mean squared error--MSE), dan kesalahan persentase rata-rata yang absolut (mean absolute percent error--MAPE). Tetapi disini akan ditambahkan kesalahan ratarata (mean error--ME) sebagai acuan pertama mencari nilai error

a) ME (Mean Error) atau Nilai Rata-Rata Kesalahan

\section{$\mathrm{ME}=\frac{\sum \text { Aktual }- \text { Peramalan }}{\mathrm{n}}$}

b) MAD (Mean Absolute Deviation) atau Nilai Deviasi Rata-Rata Kesalahan Absolute

$$
\mathrm{MAD}=\frac{\Sigma \mid \text { Aktual }- \text { Peramalan } \mid}{\mathrm{n}}
$$

c) MSE (Mean Square Error) atau Nilai Rata-Rata Kesalahan Kuadrat

$$
\mathrm{MSE}=\frac{\Sigma \mid \text { Aktual }- \text { Peramalan }^{2}}{\mathrm{n}}
$$

d) MAPE (Mean Absolute Percent Error) atau Nilai Rata-Rata Kesalahan Persentase Absolute

$$
\begin{aligned}
& \text { MAPE }= \\
& \frac{\sum_{i-1}^{n} 100 \mid \text { Aktual }_{i}-\text { Aktual }_{i} \mid / \text { Aktual }_{i}}{n}
\end{aligned}
$$

\section{Analisis dan Pembahasan Deskripsi Data}

Data yang diperlukan dalam penelitian ini diperoleh melalui instrument kuesioner yang berisi data historis penjualan perbulan selama 3 tahun ( tahun 2015, 2014 dan 2013 ) dari responden dan data dari hasil wawancara kepada produsen sekaligus pedagang ditambah dari pengurus dan ketua koperasi GAPEBTA, tabel 1.

Tabel 1

Data Penjualan Bordir Tasikmalaya Toko A Jan 2013 s/d Des 2015

\begin{tabular}{ll}
\hline Month & Actual \\
\hline Jan-13 & 105 \\
\hline Feb-13 & 115 \\
\hline Mar-13 & 130 \\
\hline Apr-13 & 130 \\
\hline May-13 & 120 \\
\hline Jun-13 & 130 \\
\hline Jul-13 & 140 \\
\hline Aug-13 & 115 \\
\hline Sep-13 & 125 \\
\hline Oct-13 & 120 \\
\hline Nov-13 & 130 \\
\hline Des-13 & 140 \\
\hline
\end{tabular}

\begin{tabular}{ll}
\hline Month & Actual \\
\hline Jan-14 & 145 \\
\hline Feb-14 & 155 \\
\hline Mar-14 & 170 \\
\hline Apr-14 & 170 \\
\hline May-14 & 160 \\
\hline Jun-14 & 175 \\
\hline Jul-14 & 190 \\
\hline Aug-14 & 150 \\
\hline Sep-14 & 165 \\
\hline Oct-14 & 160 \\
\hline Nov-14 & 170 \\
\hline Des-14 & 190 \\
\hline
\end{tabular}

\begin{tabular}{ll}
\hline Month & Actual \\
\hline Jan-15 & 220 \\
\hline Feb-15 & 235 \\
\hline Mar-15 & 245 \\
\hline Apr-15 & 240 \\
\hline May-15 & 245 \\
\hline Jun-15 & 270 \\
\hline Jul-15 & 280 \\
\hline Aug-15 & 250 \\
\hline Sep-15 & 250 \\
\hline Oct-15 & 240 \\
\hline Nov-15 & 250 \\
\hline Des-15 & 275 \\
\hline
\end{tabular}

data periodik, trend dan musiman.
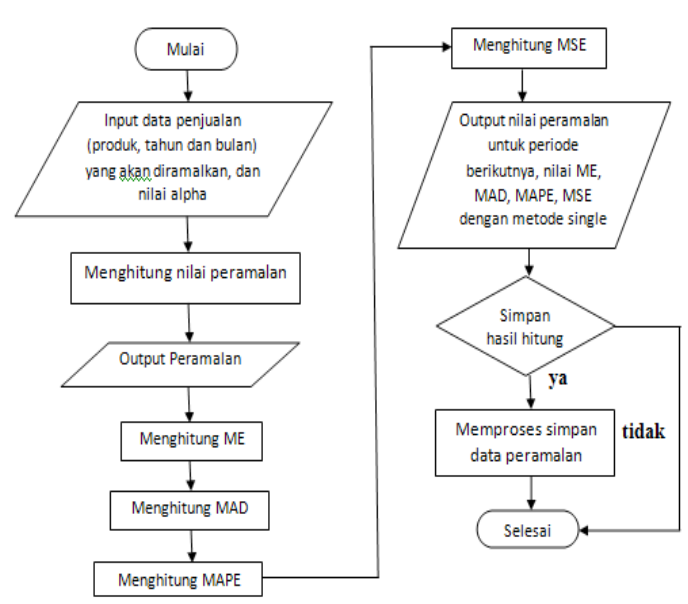

Dari data di atas akan dijadikan bentuk grafik untuk dapat di analisis berdasarkan

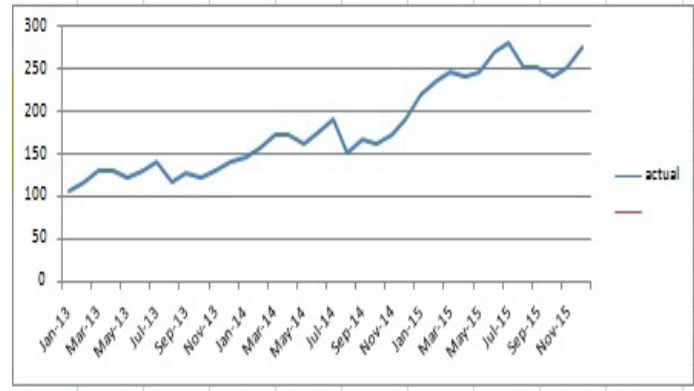

Gambar 1. Grafik Penjualan Bordir Tasikmalaya Toko A Jan 2013 - Des 2015

Dari data di atas akan diolah dengan 3 model pemulusan (single, double dan triple 
exponential smoothing) menggunakan sistem peramalan yang dibuat dengan editor NetBeans berbahasa pemrograman Java dan basis data menggunakan MySQL berdasarkan rancangan sistem yang dibuat dengan flowchart

\section{Flowchart Sistem}

Bagan Alir (flowchart) digunakan untuk alat bantu komunikasi dan untuk dokumentasi (Pressman, 2010). Flowchart untuk sistem ini dibagi menjadi 3 flowchart untuk masingmasing peramalan (single exponential smoothing, double exponential smoothing dan triple exponential smoothing), tetapi pada penelitian ini flowchart yang diberikan hanya flowchart untuk peramalan single exponential smoothing. Berikut flowchart sistem untuk peramalan single exponential smoothing.

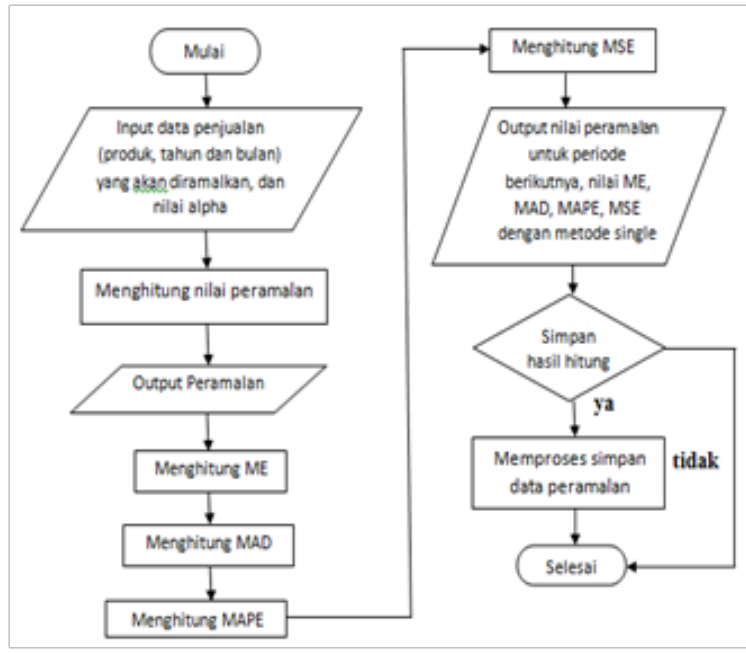

Gambar 2.Flowchart sistem peramalan dengan perhitungan single exponential smoothing

Bagan alir program perhitungan di atas dapat dijelaskan sebagai berikut :

1. Memasukkan data penjualan yang akan diramalkan dan nilai alpha

2. Menghitung nilai peramalan

3. Keluaran untuk proses perhitungan peramalan

4. Menghitung nilai Mean Error (ME)

5. Menghitung nilai Mean Absolute Deviation (MAD)

6. Menghitung nilai Mean Percentage Error (MAPE)

7. Menghitung nilai Mean Square Error
(MSE)

8. Keluaran untuk ramalan periode berikutnya serta nilai ME, MAD, MAPE, MSE dengan metode single exponential smoothing.

9. Jika ingin menyimpan hasil peramalan maka komputer akan memproses penyimpanan data kemudian selesai. Jika tidak maka selesai.

\section{HASIL DAN PEMBAHASAN}

Tampilan awal dari sistem peramalan yang sudah dibuat dapat dilihat pada gambar 3 .

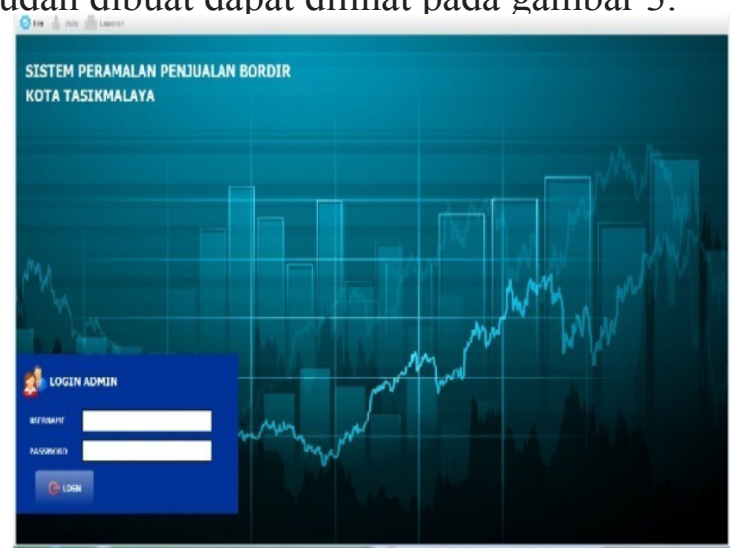

Gambar 3 Tampilan awal dari sistem peramalan

Proses awal dari sistem peramalan ini adalah dengan menginput data barang berdasarkan kode barang, nama barang dan jumlah penjualan barang (nilai aktual).

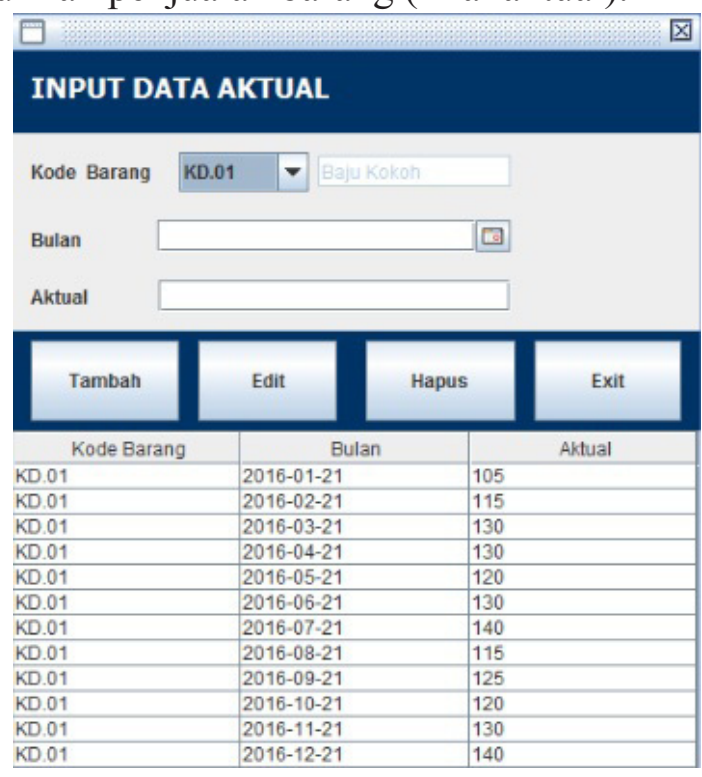

Gambar 4

Form input sistem peramalan

Proses selanjutnya adalah perhitungan 
nilai peramalan dengan ke 3 metode peramalan (single, double, dan triple exponential smoothing). Dan berikut adalah hasil perhitungan peramalannya.

\section{Tabel 2}

Hasil Perhitungan Metode Single Exponential Smoothing

\begin{tabular}{lll}
\hline Month & Actual & Forecast \\
\hline Jan-13 & 105 & 105 \\
\hline Feb-13 & 115 & 105 \\
\hline Mar-13 & 130 & 114 \\
\hline Apr-13 & 130 & 128 \\
\hline May-13 & 120 & 130 \\
\hline Jun-13 & 130 & 121 \\
\hline Jul-13 & 140 & 129 \\
\hline Aug-13 & 115 & 139 \\
\hline Sep-13 & 125 & 117 \\
\hline Oct-13 & 120 & 124 \\
\hline Nov-13 & 130 & 120 \\
\hline Des-13 & 140 & 129 \\
\hline
\end{tabular}

\begin{tabular}{lll}
\hline Month & Actual & Forecast \\
\hline Jan-14 & 145 & 139 \\
\hline Feb-14 & 155 & 144 \\
\hline Mar-14 & 170 & 154 \\
\hline Apr-14 & 170 & 168 \\
\hline May-14 & 160 & 170 \\
\hline Jun-14 & 175 & 161 \\
\hline Jul-14 & 190 & 174 \\
\hline Aug-14 & 150 & 188 \\
\hline Sep-14 & 165 & 154 \\
\hline Oct-14 & 160 & 164 \\
\hline Nov-14 & 170 & 160 \\
\hline Des-14 & 190 & 169
\end{tabular}

\begin{tabular}{lll}
\hline Month & Actual & Forecast \\
\hline Jan-15 & 220 & 188 \\
\hline Feb-15 & 235 & 217 \\
\hline Mar-15 & 245 & 233 \\
\hline Apr-15 & 240 & 244 \\
\hline May-15 & 245 & 240 \\
\hline Jun-15 & 270 & 245 \\
\hline Jul-15 & 280 & 267 \\
\hline Aug-15 & 250 & 279 \\
\hline Sep-15 & 250 & 253 \\
\hline Oct-15 & 240 & 250 \\
\hline Nov-15 & 250 & 241 \\
\hline Des-15 & 275 & 249 \\
\hline
\end{tabular}

Berdasarkan hasil perhitungan dari Single Exponential Smoothing Model dengan menggunakan nilai $\alpha=0.1,0.5$ dan 0.9, maka didapat nilai error terkecil dengan menggunakan 4(empat) metode yang memperoleh hasil $\mathrm{ME}=5, \mathrm{MAD}=13$, MAPE $=7 \%$ dan $\mathrm{MSE}=241$, yaitu dari nilai $\alpha=$ 0.9 . Nilai $\alpha$ inilah yang akan digunakan untuk

Tabel 3

Hasil Perhitungan Nilai Kesalahan Metode Single Exponential Smoothing

\begin{tabular}{|l|c|c|c|}
\hline Nilai Kesalahan & $\alpha=0.1$ & $\alpha=0.5$ & $\alpha=0.9$ \\
\hline ME & 33 & 9 & 5 \\
\hline MAD & 34 & 15 & 13 \\
\hline MAPE & $17 \%$ & $8 \%$ & $7 \%$ \\
\hline MSE & 1667 & 319 & 241 \\
\hline
\end{tabular}

Tabel 4

Hasil Perhitungan Metode Double Exponential Smoothing

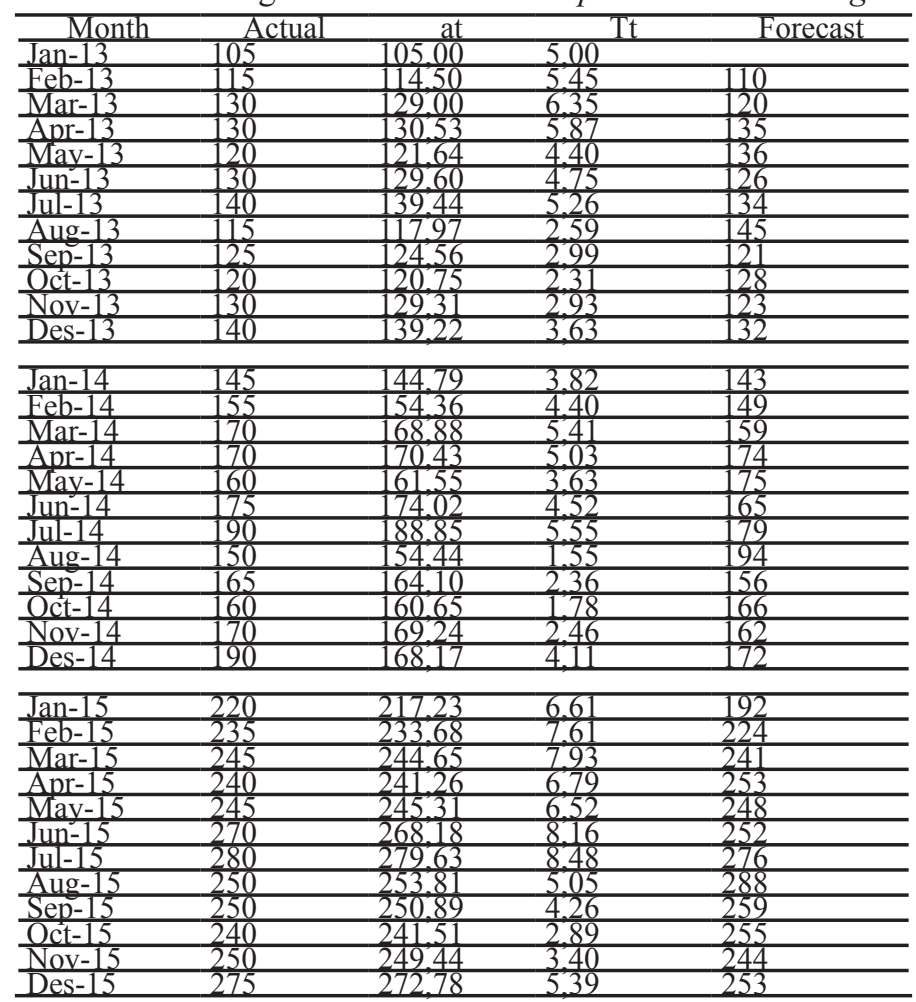




\section{Perhitungan Double Exponential} Smoothing Model yang dilaksanakan dengan menggunakan kombinasi nilai $\alpha=$ $0,1,0,5,0,9$ dan nilai $\beta=0,1,0,5,0,9$. Dari hasil perhitungan didapat hasil nilai error yang terkecil yaitu: $\mathrm{ME}=-1, \mathrm{MAE}=12$, MAPE $=7 \%$, MSE $=246$ yang diperoleh dari kombinasi nilai $\alpha=0,9$ dan nilai $\beta$ $=0,1$. Model Double Exponential Smoothing mempunyai kinerja yang bagus dalam

Tabel 5

Hasil Perhitungan Nilai Kesalahan Metode Double Exponential Smoothing

\begin{tabular}{|l|l|l|l|l|l|l|l|l|l|}
\hline \multirow{2}{*}{$\begin{array}{l}\text { Nilai } \\
\text { Kesalahan }\end{array}$} & \multicolumn{9}{|c|}{ Kombinasi $\alpha=0.1,0.5,0.9$ dan $\beta=0.1,0.5,09$} \\
\cline { 2 - 11 } & $\alpha=0.1$ & $\alpha=0.1$ & $\alpha=0.1$ & $\alpha=0.5$ & $\alpha=0.5$ & $\alpha=0.5$ & $\alpha=0.9$ & $\alpha=0.9$ & $\alpha=0.9$ \\
& $\beta=0.1$ & $\beta=0.5$ & $\beta=0.9$ & $\beta=0.1$ & $\beta=0.5$ & $\beta=0.9$ & $\beta=0.1$ & $\beta=0.5$ & $\beta=0.9$ \\
\hline ME & 1 & 0 & -2 & 0 & 0 & 1 & 0 & 0 & 1 \\
\hline MAD & 17 & 20 & 21 & 13 & 14 & 15 & 12 & 13 & 15 \\
\hline MAPE & $9 \%$ & $10 \%$ & $12 \%$ & $7 \%$ & $8 \%$ & $8 \%$ & $7 \%$ & $8 \%$ & $9 \%$ \\
\hline MSE & 426 & 552 & 632 & 281 & 338 & 340 & 239 & 299 & 371 \\
\hline
\end{tabular}

Tabel 6

Hasil Perhitungan Metode Triple Exponential Smoothing

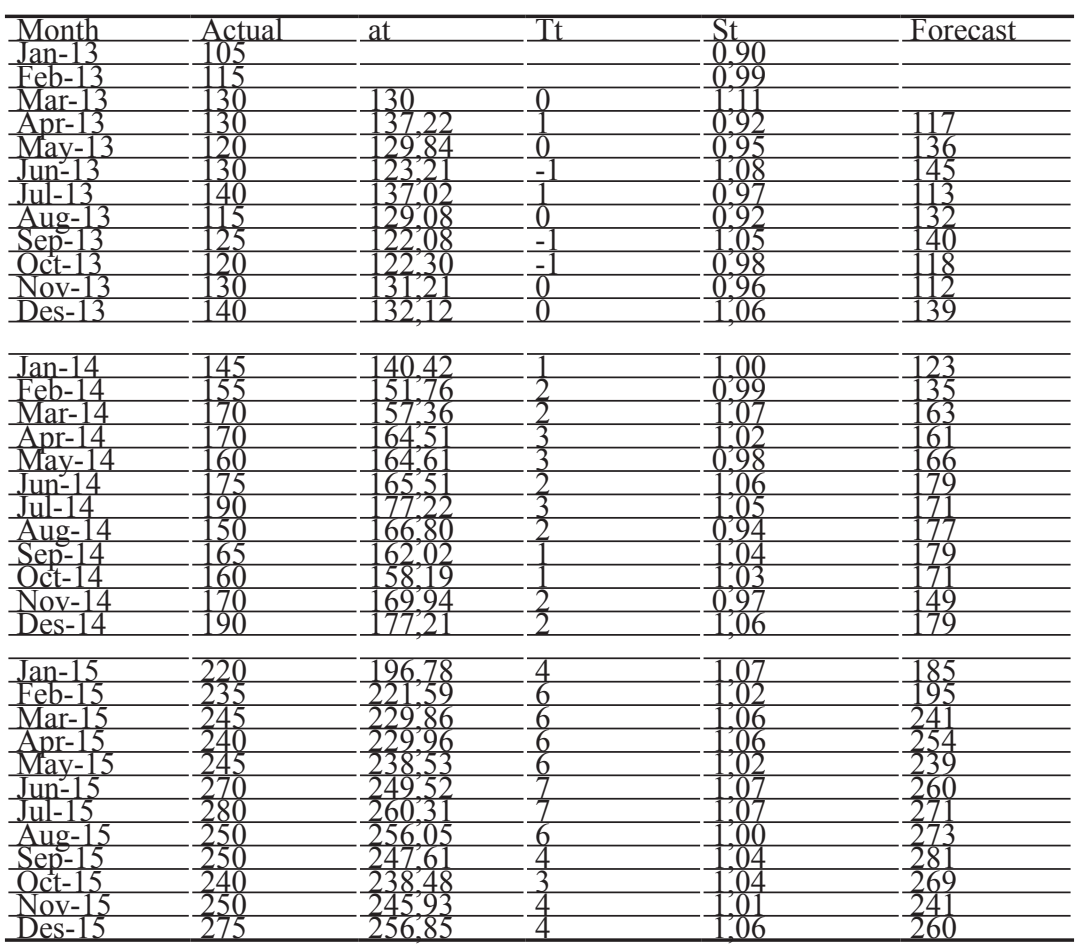

Tabel 7

Hasil Perhitungan Nilai Kesalahan Metode Triple Exponential Smoothing

\begin{tabular}{|l|c|c|c|c|}
\hline \multicolumn{1}{|c|}{ Nilai Kesalahan } & ME & MAD & MAPE & MSE \\
\hline$\alpha=0.1, \beta=0.1, \gamma=0.1$ & 15 & 22 & $11 \%$ & 792 \\
\hline$\alpha=0.1, \beta=0.5, \gamma=0.1$ & 1 & 21 & $11 \%$ & 614 \\
\hline$\alpha=0.1, \beta=0.9, \gamma=0.1$ & -1 & 24 & $13 \%$ & 776 \\
\hline$\alpha=0.5, \beta=0.1, \gamma=0.1$ & 1 & 17 & $10 \%$ & 480 \\
\hline$\alpha=0.5, \beta=0.5, \gamma=0.1$ & -1 & 20 & $11 \%$ & 551 \\
\hline$\alpha=0.5, \beta=0.9, \gamma=0.1$ & 0 & 21 & $12 \%$ & 603 \\
\hline$\alpha=0.9, \beta=0.1, \gamma=0.1$ & -1 & 23 & $13 \%$ & 821 \\
\hline$\alpha=0.9, \beta=0.5, \gamma=0.1$ & -2 & 27 & $15 \%$ & 1150 \\
\hline$\alpha=0.9, \beta=0.9, \gamma=0.1$ & -2 & 35 & $19 \%$ & 1698 \\
\hline$\alpha=0.1, \beta=0.1, \gamma=0.5$ & 10 & 20 & $11 \%$ & 560 \\
\hline$\alpha=0.1, \beta=0.5, \gamma=0.5$ & 1 & 19 & $10 \%$ & 576 \\
\hline$\alpha=0.1, \beta=0.9, \gamma=0.5$ & -1 & 20 & $11 \%$ & 674 \\
\hline
\end{tabular}


Perhitungan Model Triple Exponential Smoothing dengan Multiplicative Seasonal Model dengan menggunakan kombinasi $\alpha$ $=0,1,0,5,0,9$ dan $\beta=0,1,0,5,0,9$ serta $\gamma$ $=0,1,0,5,0,9$. Hasil perhitungan didapatkan error terkecil yaitu $\mathrm{ME}=2, \mathrm{MAE}=16$, $\mathrm{MAPE}=9 \%$ dan MSE $=329$ dari kombinasi $\alpha=0,5, \beta=0,1$ dan $\gamma=0,5$. Metode Triple Exponential Smoothing dengan Multiplicative Seasonal Model menyatakan bahwa dari hasil perbandingan peramalan tersebut yang memiliki error yang terkecil akan digunakan sebagai informasi prediksi penjualan produk untuk periode berikutnya. Selanjutnya metode ini digunakan ketika menunjukan adanya trend dan perilaku musiman serta lebih cocok untuk membuat ramalan yang berfluktuatif atau mengalami gelombang pasang surut.

\section{SIMPULAN}

Dari hasil penelitian yang telah dilakukan, maka dapat diambil beberapa kesimpulan sebagai berikut:

a. Hasil perhitungan dengan metode Single Exponential Smoothing digunakan untuk peramalan dalam jangka pendek biasanya satu bulan kedepan. Data dari hasil perhitungannya berfluktuasi disekitar nilai mean (rata-rata) yang tetap tanpa trend dan pertumbuhan. b. Hasil perhitungan dengan metode Double Exponential Smoothing mempunyai performance yang bagus dalam meramalkan. Hal tersebut ditunjukan dengan pola data yang kecenderungan naik

c. Hasil perhitungan dengan metode Triple Exponential Smoothing dengan Multiplicative Seasonal Model menunjukan bahwa dengan melaksanakan pemulusan sebanyak tiga kali yaitu nilai level,nilai trend dan nilai estimasi musiman. Dengan hal tersebut diharapkan dapat memberikan hasil data peramalan yang mendekati kenyataan.

d. Setelah peneliti melakukan pengolahan data berdasarkan data historis penjualan dari responden dengan pengujian trialand error untuk semua metode (single exponential smoothing, double exponential smoothing dan triple exponential smoothing dengan Multiplicative Seasonal Model), maka dapat disimpulkan grafik dari data penjualan responden berbeda untuk setiap responden tergantung dari data historisnya

\section{DAFTAR RUJUKAN}

Heizer, Jay, Barry, Render. (2015). Manajemen Operasi, Edisi 11,Jakarta: Salemba Empat.

Assauri, Sofjan, (2016), Manajemen OperasiProduksiEdisi 3, Jakarta: PT RajaGrafindo Persada.

Stevenson, William J and Sum Chee Chuong. (2014), Operations Management ; An Asian Prespective.Jakarta: Salemba Empat.

Pressman, Roger S.(2010). Software Engeneering A Practitioner Approach (7 $7^{\text {th }}$ Edition). New York : McGraw Hill 